\title{
Cost and Return Analysis of Rain Fed Lowland Rice Production under Smallholder Farmers in Fogera District, North Western Ethiopia
}

\author{
Shewaye Abera ${ }^{1^{*}}$, Adam Bekele ${ }^{2}$, Abebaw Assaye ${ }^{1}$, Adane Melak ${ }^{3}$ \\ ${ }^{1,3}$ Fogera National Rice Research and Training center, Ethiopian Institute of Agricultural Research, Ethiopia \\ ${ }^{2}$ Melkassa Agricultural Research Center, Ethiopian Institute of Agricultural Research, Ethiopia \\ *Corresponding Author: Shewaye Abera, Fogera National Rice Research and Training center, Ethiopian \\ Institute of Agricultural Research, Ethiopia
}

\begin{abstract}
This study was designed to estimate cost of production of rice and assessing its profitability under smallholder farmers in lowland agroecologies of Fogera plain, Ethiopia. Descriptive statistics and enterprise budget were used to analyze data collected from selected farmers. The finding of the study reveals the average productivity of rice was3.6 tone per hectare. The labor cost was the main cost item in rice production which took about $70 \%$ of the total variable cost, and followed by material and animal power costs. From the total operational costs weeding cost took the maximum share about $44.56 \%$. The enterprise budget analysis result indicates that sampled farmers obtained a profit margin of $49.51 \%$ per hectare with benefit cost ratio of 1.98 , and breakeven price and yield of 4.66 ETB per $\mathrm{kg}$ and $2064 \mathrm{~kg}$ per hectare. Moreover, gross margin of rice production is more sensitive for grain price and yield fluctuations than input costs. Thus, rice production is a profitable enterprise and the study suggest that research institution should focus on developing and promoting productivity improving and labor saving technologies. In addition, to reduce price fluctuation strengthen the market information delivery system and group marketing
\end{abstract}

Keywords: Smallholder farmer, Gross margin analysis, Sensitivity and Break-even analysis

\section{INTRODUCTION}

Rice is a recent introduction in Ethiopia; an attempt to introduction of rice had probably been started in Ethiopia when the wild rice was observed in the swampy and waterlogged areas of Fogera and Gambella Plains (Gebey et al., 2012). According to the report of MoA (2010), the potential rain fed rice production area is estimated about 30 million hectares, of which more than 5 million hectares are highly suitable.

The importance of rice is being well recognized in the country as the area under cultivation, production and productivity increased within the period of the two decades by $88 \%, 92 \%$ and $34 \%$, respectively (FAOSTAT, 2015). In productivity base, it is the second more productive cereal crop next to maize (CSA, 2014). It has shown promise as to be among the major crops that can immensely contribute towards ensuring food security in Ethiopia.

Rice is cultivating in all regions of Ethiopia (MoA, 2010). Of all rice producing regions Amhara took the maximum share of rice production about $86 \%$ of the national rice production of which $91 \%$ of the region rice production was came from Fogera plain (CSA, 2015).

The current five-year plan, GTP II, gave due consideration for rice production. Rice seen as a priority crop to ensure food security through increasing the average productivity from 2.7 tons per ha in 2015 to 4.1 tons per ha in 2020 and increased the total volume of produce from 1300 tons in 2015 to 2030 tons by the year 2020 .

Beside the increase in production and productivity of rice, the national production is being covering about $30 \%$ of the demand and hence country has been importing a huge amount of rice in order to cover the national demand (FAOSTAT, 2015, CSA, 2015). Thus, knowing the production economics of rice farming was became very important so as to show the possible avenues for technological 
investment planning to enhance productivity, promote income generation and to serve the new entrants in to the enterprise for the utilization of the potential and fill the huge demand gap.

Therefore, the study was designed to estimate costs of production and assessing profitability of rain fed lowland rice cultivation under smallholder farmers' condition in Fogera plain. Hence, the analysis would provide a valuable insight on production cost components and input output relation of the enterprise.

\section{MeTHODOLOGY}

\subsection{Description of the Study Area}

The study was conducted in Fog era district of South Gondar Zone of Amhara Regional State, Ethiopia. The area is situated $11^{0} 46$ to $11^{0} 59$ latitude north and $37^{0} 30$ to $37^{0} 52$ longitude east. Altitude ranges from 1774 to 2410 meter above sea level with mean annual rain fall of $1216 \mathrm{~mm}$ and mean annual temperature of $19^{\circ} \mathrm{c}$. Farmer depends on long rainy season for crop production and crop livestock mixed farming system is a common practice in the area. Rib and Gumera are the two major rivers that cross many of rice producing kebeles and flooding the plain. The two rivers have economic importance to the areas as they are used for irrigation purpose for vegetables production during the dry season.

\subsection{Data Collection and Analysis}

Two stage random sampling were used in the study. In the first stage four kebeles were selected randomly from the list of rain fed lowland rice growing kebeles of Fogera district. Then, given the selected kebeles households were selected randomly and the sample distribution followed probability proportional to size of households. Plot level data were collected from sample households through interview. The collected data was then analyzed using descriptive statistics such as mean, standard deviation, frequency and percentages as well as gross margin sensitivity and break even analysis.

\subsection{Gross Margin Analysis}

Gross margin analysis was employed to better understand the relationship between sales revenue and cost structures (Kay, 1986) and used to evaluate the viability of rice production enterprise to enable better decision making

\section{GM = TR - TVC}

Where GM is gross margin per hectare, TR is total revenue calculated as the product of the prevailing market price per unit output and the amount of paddy and straw produced per hectare and TVC is total variable cost that varies with the level of production and includes expenditure on inputs like seeds, fertilizer and labor etc.

\subsection{Sensitivity Analysis}

A sensitivity analysis was undertaken to assess the risk bearing ability of rice production under varying circumstance of price and yield. The grain price and yield of rice were varied by $10 \%$ and $25 \%$ above and below the received yield and price of rice farming.

\subsection{Break Even Analysis}

An enterprise, whether or not a profit maximize, often finds it useful to know what price (or output level) must be for total revenue just equal total cost. This can be done with a break even analysis. This analysis is used to determine the minimum level of output that allows the firm to break even.

$$
\text { Break }- \text { even sale price }=\frac{\text { Total cost }}{\text { Total production }(y \text { ield })}
$$

If unit farm-gate prices are higher than the break-even price, the farm operation makes an economic profit

$$
\text { Break }- \text { even yield }=\frac{\text { Total cost }}{\text { Sale price }}
$$


If per hectare yields are higher than the break-even yield, the farm operation makes an economic profit.

\section{RESULTS AND DISCUSSION}

\subsection{Socio-Demographic Characteristics of Respondents}

The majority of the sample households $(81 \%)$ were male. Regarding the education status of the household head, $54.2 \%$ of the sample households were illiterate, and $27.1 \%$ and $18.7 \%$ were capable of reading and writing and had attended at most primary school and above, respectively(Table 1).

Table1. Socio-Demographic Characteristics of Respondents

\begin{tabular}{|c|c|c|}
\hline Variable & Frequency & Percent \\
\hline Sex & & 81 \\
\hline Male & 39 & 19 \\
\hline Female & 9 & $\mathbf{1 0 0}$ \\
\hline Total & $\mathbf{4 8}$ & 54.2 \\
\hline Education & 26 & 27.1 \\
\hline Illiterate & 13 & 16.7 \\
\hline Read \&write/ Religious school & 8 & 2.0 \\
\hline Primary and junior secondary(1- & & $\mathbf{1 0 0}$ \\
\hline 8) & 1 & $\mathbf{4 8}$ \\
\hline Secondary school(9-12) & & \\
\hline Total & & \\
\hline
\end{tabular}

Source: own calculation

The mean age of household head was 49 years and household size of the sample household's were 4.73 persons. On average the sample households own 0.85 hectare of cultivated land of which on average 0.62 hectare were allocated for rice production. The sample households also owned 5.55 TLU of livestock (Table 2).

Table2. Socio-Demographic Characteristics of Respondents

\begin{tabular}{|c|c|c|c|c|}
\hline Variable & Mean & Std.dev. & Min & Max \\
\hline Age & 49 & 14.75 & 19 & 77 \\
\hline Household Size & 4.73 & 2.02 & 2 & 10 \\
\hline Cultivated land size & 0.85 & 0.52 & 0.25 & 2.5 \\
\hline Rice cultivated land & 0.62 & 0.34 & 0.25 & 1.88 \\
\hline Livestock Ownership(TLU) & 5.55 & 2.78 & 0.76 & 14.52 \\
\hline
\end{tabular}

Source: own calculation

On the basis of land allocated to rice production the sample households were categorized in to three groups, viz small $(<0.5 \mathrm{ha})$, medium $(0.5-1 \mathrm{ha})$ and large above 1 ha. Out of the total sample households the majority $65 \%$ were allocated medium land size for rice production followed by small land size and few of them were allocated land more than a hectare of land for rice production. Regarding the productivity all categories of land size were produced more than 3 tons per hectare which was more than the national average of 2.8 tons per hectare (Table 3 ).

Table3. Land under rice production and attained yield by sample household

\begin{tabular}{|c|c|c|c|}
\hline Category & Frequency & Percent & Yield(tons) \\
\hline Small $(<0.5$ ha $)$ & 13 & 27 & 3.5 \\
\hline Medium $(0.5-1 \mathrm{ha})$ & 31 & 65 & 3.8 \\
\hline Large $(>1 \mathrm{ha})$ & 4 & 8 & 3.4 \\
\hline Total & 48 & 100 & \\
\hline
\end{tabular}

Source: own calculation

\subsection{Cost of Rice Production}

Table 4 indicates that the per hectare total variable cost of rain fed lowland rice has two components that are material cost and cost of cultural practices. The result reveals the total variable cost of rain fed lowland rice was ETB 16,737.68 per hectare. 
Cost and Return Analysis of Rain Fed Lowland Rice Production under Smallholder Farmers in Fogera District, North Western Ethiopia

Cost of cultural practices was the cost item which took the maximum share in total variable cost of rice production i.e. $79.66 \%$. On average ETB 13,332.95 was incurred for cultural practices of rain fed lowland rice production of which weeding cost took the lion share $(44.65 \%)$, followed by harvesting and pileup (15.62\%), land preparation (14.72\%) and threshing and winnowing (11.38\%) costs were the major cost items of cultural practices.

Table4. Per hectare costs of rain fed lowland rice production

\begin{tabular}{|c|c|c|c|c|c|c|c|}
\hline Cost Items & Obs & $\begin{array}{l}\text { Mean } \\
(\text { ETB })\end{array}$ & Std.dev & \begin{tabular}{|c|}
$\%$ share of total \\
variable costs(TVC)
\end{tabular} & $\begin{array}{l}\text { \% share within } \\
\text { components }\end{array}$ & Min & Max \\
\hline Material cost & & $3,404.74$ & & 20.34 & 100 & 660 & 7334 \\
\hline Seed & 48 & 1906.45 & 641.45 & 11.39 & 56.0 & 660 & 3890 \\
\hline Fertilizer & 48 & 1498.29 & 1074.12 & 8.95 & 44.0 & 0 & 3564 \\
\hline $\begin{array}{c}\text { Cost of Cultural } \\
\text { practices }\end{array}$ & & $13,332.95$ & & 79.66 & 100 & 6275 & 34141 \\
\hline Land preparation & 48 & 1962.87 & 685.77 & 11.73 & 14.72 & 1165 & 4852 \\
\hline $\begin{array}{c}\text { Water } \\
\text { Management }\end{array}$ & 48 & 62.38 & 94.33 & 0.37 & 0.47 & 0 & 345 \\
\hline Planting & 48 & 548.65 & 341.82 & 3.28 & 4.12 & 137 & 1733 \\
\hline Weeding & 48 & 5949.47 & 4262.65 & 35.57 & 44.65 & 2015 & 15660 \\
\hline $\begin{array}{c}\text { Fertilizer } \\
\text { Application }\end{array}$ & 48 & 63.78 & 51.97 & 0.29 & 0.37 & 0 & 255 \\
\hline $\begin{array}{l}\text { Harvesting and } \\
\text { Pileup }\end{array}$ & 48 & 2083.18 & 1979.54 & 12.45 & 15.62 & 543 & 11020 \\
\hline $\begin{array}{l}\text { Threshing and } \\
\text { winnowing }\end{array}$ & 48 & 1516.92 & 684.52 & 9.06 & 11.38 & 706 & 3610 \\
\hline Transporting & 48 & 1156.24 & 1325.59 & 6.91 & 8.67 & 360 & 6965 \\
\hline $\begin{array}{l}\text { Total variable } \\
\text { cost (TVC) }\end{array}$ & & $16,737.68$ & & 100 & & 8035 & 36241 \\
\hline
\end{tabular}

Source: own calculation

The material cost of rain fed lowland rice production was ETB 3,404.74 which includes the cost of seed and fertilizer. The contribution of material cost for total variable cost was $20.34 \%$. About $56 \%$ of the total cost of material was seed cost and the rest $44 \%$ of the total material cost goes to fertilizer expenditure (Table 4).

Table5. Per Hectare Returns of Rain fed Lowland Rice Production

\begin{tabular}{|c|c|c|c|c|}
\hline Item & Mean & Std. dev & Min & Max \\
\hline Paddy & $29,155.45$ & $8,576.62$ & 16,220 & 48,660 \\
\hline Straw & $4,021.25$ & $1,417.79$ & 1,400 & $7,466.67$ \\
\hline Total return(TR) & $\mathbf{3 3 , 1 7 6 . 7 0}$ & $\mathbf{9 2 4 8 . 4 5}$ & $\mathbf{1 9 , 4 2 0}$ & $\mathbf{5 3 , 7 3 6 . 4 4}$ \\
\hline
\end{tabular}

Source: own calculation

\subsection{Returns of Rice Production}

To generate returns of rice production under smallholder farmers have two components that are the paddy main component and the bi-product (straw) component. The mean values of both components were considered to compute the gross returns of rice production. As indicated in Table 5 the mean value of paddy ETB 29,135.17 and the value of straw ETB 4,021.25 with gross return of ETB $33,156.42$ per hectare.

Table6. Distribution of Revenue from Rice Production

\begin{tabular}{|c|c|c|c|}
\hline Total revenue (ETB/ha) & Frequency & percent & Cumulative Percent \\
\hline$<20000$ & 1 & 2 & 2 \\
\hline $20000-35000$ & 32 & 67 & 69 \\
\hline $35001-50000$ & 11 & 23 & 92 \\
\hline$>50000$ & 4 & 8 & 100 \\
\hline Total & 48 & 100 & \\
\hline
\end{tabular}

Source: own calculation 
The sample households earned total revenue of ranging from ETB 19,420 to ETB 53,736.44. Table 6indicates that the majority of the sample households (67\%) were earned an income between 20,000 to $35,000 \mathrm{ETB} /$ ha from rice production.

Table7. Gross margin Analysis

\begin{tabular}{|c|c|c|c|c|c|}
\hline Variables & Obs & Mean & \multicolumn{2}{|c|}{ Std.Err } & \multicolumn{2}{|c|}{ 95\% confidence interval } \\
\hline Total Return(TR) & 48 & $33,156.43$ & $1,334.89$ & $30,470.96$ & $35,841.90$ \\
\hline Total Variable cost(TVC) & 48 & $16,737.65$ & $1,031.73$ & $14,662.94$ & $18,814.09$ \\
\hline Gross Margin(TR_TVC) & $\mathbf{4 8}$ & $\mathbf{1 6 , 4 1 7 . 9 2}$ & $\mathbf{1 , 5 9 0 . 0 4}$ & $\mathbf{1 3 , 2 1 9 . 1 6}$ & $\mathbf{1 9 , 6 1 6 . 6 7}$ \\
\hline BenefitCost Ratio (BCR) & & $\mathbf{1 . 9 8}$ & & & \\
\hline Profit margin (\%) & & $\mathbf{4 9 . 5 1}$ & & & \\
\hline Break even Yield (kg) & & $\mathbf{2 0 6 4}$ & & & \\
\hline Breakeven price (ETB) & & $\mathbf{4 . 6 6}$ & & & \\
\hline
\end{tabular}

Source: own calculation

Table 7: presents on average the sample households earned total revenue of ETB 33,156.43 per hectare and incurred a total variable cost of ETB 16,737.65 per hectare. Thus, an average rice farmer earned a gross margin of ETB 16417.92 which constituting about $50 \%$ of the total revenue earned as a profit margin of rain fed lowland rice production with a benefit cost ratio of 1.98 . The implication is that a one Birr investment on factors of production lowland rice production would earn birr 1.98. This implies that rice is a profitable enterprise in the study area.

The breakeven price was found to be ETB 4.66 per kilogram whereas break even yield was 2,064 kg. At this point of yield per hectare and price ETB per $\mathrm{kg}$ or a decline in yield up to 2064 kilogram per hectare or price drop of up to ETB 4.66 per kg, rain fed lowland rice would not be at loss or gain. The implication is that break even analysis of rice production resists a large drop of yield and price before incurring a loss.

Table8. Sensitivity Analysis of Rain Fed Lowland Rice Production

\begin{tabular}{|c|c|c|c|c|c|c|c|c|}
\hline Item & $\begin{array}{c}\text { Origin } \\
\text { al }\end{array}$ & $\begin{array}{c}\mathbf{1 0 \%} \\
\text { Increase } \\
\text { in price }\end{array}$ & $\begin{array}{c}\mathbf{1 0 \%} \\
\text { Decrease } \\
\text { in price }\end{array}$ & $\begin{array}{c}\mathbf{1 0} \% \\
\text { Increase in } \\
\text { yield }\end{array}$ & $\begin{array}{c}\mathbf{1 0 \%} \\
\text { Decrease in } \\
\text { yield }\end{array}$ & $\begin{array}{c}\mathbf{1 0 \%} \\
\text { Increase in } \\
\text { input cost }\end{array}$ & $\begin{array}{c}\mathbf{1 0 \%} \\
\text { Decrease in } \\
\text { input cost }\end{array}$ & $\begin{array}{c}\mathbf{1 0} \% \text { increase in } \\
\text { input cost and } \\
\text { decrease in yield }\end{array}$ \\
\hline $\begin{array}{c}\text { TR } \\
\text { (ETB/ha) }\end{array}$ & 33,156 & 36,716 & 29,663 & 36,516 & 29,876 & 33,156 & 33,156 & 29,876 \\
\hline $\begin{array}{c}\text { TVC } \\
\text { (ETB/ha })\end{array}$ & 16,739 & 16,739 & 16,739 & 16,739 & 16,739 & $18,412.9$ & $15,065.1$ & $18,412.9$ \\
\hline $\begin{array}{c}\text { GM } \\
\text { (ETB/ha })\end{array}$ & 16,418 & 19,977 & 12,925 & 19,777 & 13,138 & $14,743.1$ & $18,090.9$ & $11,463.1$ \\
\hline BCR & 1.98 & 2.19 & 1.77 & 2.18 & 1.78 & 1.80 & 2.20 & 1.62 \\
\hline $\begin{array}{c}\% \text { chang } \\
\text { e in GM }\end{array}$ & & 22 & -21 & 20 & -20 & -10 & 10 & -30 \\
\hline
\end{tabular}

Source: own calculation

\subsection{Sensitivity Analysis}

To assess the risk bearing ability of lowland rice production in relation to price and yield. Table 8: indicate that rain fed lowland rice production were likely to be sensitive for both price and yield and less sensitive to input cost. Ten percent decrease in price of rice brought about $21 \%$ decreases in GM. Similar percentage decrease in yield also resulted in about $20 \%$ decrease in GM. While similar percentage of increase in input cost brought about $10 \%$ decreases in gross margin. Therefore, rice production is more sensitive for price and yield than input costs.

\section{CONCLUSION AND RECOMMENDATION}

The study was designed to estimate the cost of production of rice and assessing its profitability in rain fed lowland agro ecology of Fog era plain. The major cost component of rice was labor cost which took the maximum share of the total variable cost $70 \%$ in addition; about $80 \%$ of the total variable cost was operational costs of which weeding cost took about $44.65 \%$ in lowland agro ecology. This indicates that the sector lacks appropriate labor saving technologies. 
Regarding the profitability, an average farmer was earned a profit margin about $49.51 \%$ of the total revenue with a benefit cost ratio of 1.98 and hence rice production was a profitable enterprise in lowland agro ecology. Moreover, sensitivity analysis result revealed that rice production by smallholder farmers was more sensitive for both fluctuations in price and yield than input costs.

Therefore, to improve profitability of rice production research institutions should focus on developing productivity improving and cost effective and environmental friendly labor saving weeding technologies and other management practices. In addition, development institution should focus on strengthen group marketing and market information system to minimize price fluctuation.

\section{REFERENCES}

[1] CSA (2015).Federal Democratic Republic of Ethiopia Central Statistical Agency Agricultural Sample Survey Report on Area and Production of Major Crops Private Peasant Holdings, Meher Season, VolumeI

[2] Gebey T, Lemma T, Hoekstra D, Tegegne A, Alemu B.( 2012). Participatory smallholder dairy value chain development in Fogera woreda, Ethiopia: from IPMS project interventions. IPMS Case Study. Nairobi: International Livestock Research Institute

[3] MoA (2010).Ministry of Agriculture, National Rice Research and Development Strategy of Ethiopia

[4] FAOSTAT (2015). Food and Agriculture Organization of the United Nations Statistical Database.

[5] CSA (2015).Federal Democratic Republic of Ethiopia Central Statistical Agency Agricultural Sample Survey Report on Area and Production of Major Crops Private Peasant Holdings, Meher Season, VolumeI

Citation: Shewaye Abera, et.al (2019). "Cost and Return Analysis of Rain Fed Lowland Rice Production under Smallholder Farmers in Fogera District, North Western Ethiopia” International Journal of Research Studies in Agricultural Sciences (IJRSAS), 5(3), pp. 30-35, http://dx.doi.org/10.20431/2454-6224.0503004

Copyright: () 2019 Authors. This is an open-access article distributed under the terms of the Creative Commons Attribution License, which permits unrestricted use, distribution, and reproduction in any medium, provided the original author and source are credited. 